\title{
Factors associated with birth weight in Sweden: the study of men born in 1913
}

\author{
Margaretha Eriksson, Sven Cnattingius, Kurt Svärdsudd, Gösta Tibblin
}

\begin{abstract}
Study objective - To analyse factors associated with birth weight and to evaluate the validity of obstetrical data.

Design - Obstetrical data were retrieved for singleton men born in 1913 and living in Gothenburg, Sweden in 1963. Information on birth weight, maternal age, marital status, parity, social class, proteinuria, gestational age, and place of birth (home or hospital) was obtained from these birth records.

Setting - Sweden.

Participants - Fifty year old men living in Gothenburg, Sweden, in 1963.

Main results - Obstetrical records were obtained for 524 men (65\%). Place of birth, gestational age, maternal age, parity, proteinuria, and marital status were all significantly correlated to birth weight. In multivariate analyses, place of birth, gestational age, parity, and proteinuria influenced birth weight. There was a substantial difference in mean birth weight between hospital deliveries ( $3352 \mathrm{~g}$ ) and home deliveries $(3817 \mathrm{~g})$, which could be explained only partly by sociodemographic variables. Birth weight increased with parity and gestational age in home delivered babies as well as those delivered in a hospital.

Conclusions - The validity of obstetrical records from 1913 was good. The place of birth (home or hospital) is strongly associated with birth weight and may be a confounding factor in studies of the implications of birth weight for future risk of disease or death.
\end{abstract}

(f Epidemiol Community Health 1997;51:19-23)

During the past decade Barker et al have published a number of investigations supporting the hypothesis that factors related to pregnancy have long term effects on the fetus which later may affect the risks for cardiovascular and malignant diseases. Low birth weight and a low weight increase during the first year have repeatedly been shown to be associated with increased risk of diseases later in life, especially cardiovascular disease. ${ }^{1-4}$ However, this hypothesis has been questioned by others. ${ }^{56}$ Low birth weight is more common in the lower social classes, and it may be the effect of social class during a lifetime that predisposes to later diseases. ${ }^{78}$ There may thus be potential confounding bias in these types of analyses.

In this report a number of factors possibly associated with birth weight, and the validity of data from obstetrical records, are presented for a cohort of men sampled from the general population of the city of Gothenburg, Sweden.

Study population and method

The study population is a cohort of Swedish men born in 1913 who have been followed up since 1963. The cohort has been described in detail elsewhere. ${ }^{9}$ In 1963, a systematic sample consisting of men born in 1913 on a day divisible by three (that is, the third, sixth, ninth day and so on of each month) and living in the city of Gothenburg at the age of 50 was drawn. Altogether 973 men fulfilled these criteria and were invited to participate in the study; $855(88 \%)$ agreed to participate and were examined in 1963 . The cohort has been re-examined five times (1967, 1973, 1980, 1988, and 1993) since then.

Forty four foreign-born men were excluded from this report since it was considered that it would be impossible to find their obstetrical records. For the remaining 811 men, information was retrieved by searching 200 national and local archives. Obstetrical data were obtained for 524 births (65\%). After the exclusion of 12 twins from the obstetrical records obtained, 512 singleton births remained for analysis.

Data were obtained from two types of obstetrical records - case records from hospital deliveries and midwives' record books from home deliveries. In this way, information on maternal age, marital status, parity, birth weight, gestational age, and medical status of the mother and child during delivery was obtained. In addition, the urbanisation level of the birth parish and information on occupational status of the parents were derived from the birth registries or from the ministerial books or the catechetical examination books of the birth parishes.

Maternal age was defined as age at delivery. Parity was defined as number of previous births, including stillbirths, and was for this report dichotomised into those with no previous births and those with at least one previous birth. Gestational age was estimated from the mother's last menstrual period. Proteinuria was measured as no proteinuria, trace of protein, or definite proteinuria; for this report the latter two groups were pooled into a proteinuria group. The birth parishes were divided into urban or rural according to the official classification of urbanisation level in $1910 .{ }^{10}$ Information about social class was based primarily on the occupation of the child's father. If the parents were not married or not betrothed, the mother's occupation was used. Occupational status was then grouped ac- 
Table 1 Characteristics of those whose obstetric data were retrieved compared with those whose data were not retrieved

\begin{tabular}{|c|c|c|c|c|c|c|c|c|c|c|}
\hline & \multirow[b]{2}{*}{ Total no } & \multicolumn{4}{|c|}{ Obstetric reconds retrieved } & \multicolumn{5}{|c|}{ Obstetric records not retrieved } \\
\hline & & No & $(\%)$ & Mean & $(S D)$ & No & $(\%)$ & Mean & $(S D)$ & $p$ value \\
\hline \multicolumn{11}{|l|}{1913} \\
\hline Urbanisation level & 811 & & & & & & & & & $<0.0001$ \\
\hline Urban & 382 & 324 & $(85)$ & & & 58 & (15) & & & \\
\hline Rural & 429 & 200 & (47) & & & 229 & (53) & & & \\
\hline \multicolumn{10}{|l|}{ Social class } & $<0.05$ \\
\hline I & 26 & 17 & $(65)$ & & & 9 & (35) & & & \\
\hline II & 126 & 90 & (71) & & & 36 & (29) & & & \\
\hline III & 70 & 35 & (50) & & & 35 & (50) & & & \\
\hline IV & 212 & 147 & (69) & & & 65 & (31) & & & \\
\hline $\mathrm{V}$ & 353 & 227 & (64) & & & 126 & (36) & & & \\
\hline \multirow{2}{*}{\multicolumn{10}{|c|}{$\begin{array}{l}1963 \\
\text { Social class }\end{array}$}} & \\
\hline & & & & & & & & & & NS \\
\hline I & 79 & 49 & $(62)$ & & & 30 & $(38)$ & & & \\
\hline II & 332 & 227 & (68) & & & 105 & (32) & & & \\
\hline IV & 342 & 207 & $(61)$ & & & 135 & (39) & & & \\
\hline $\mathrm{V}$ & 58 & 41 & (71) & & & 17 & (29) & & & \\
\hline \multicolumn{10}{|l|}{ Smoking habits } & NS \\
\hline Never smoked & 196 & 120 & $(61)$ & & & 76 & (39) & & & \\
\hline Ex-smokers & 158 & 109 & (69) & & & 49 & (31) & & & \\
\hline Smoking $<14 \mathrm{~g} / \mathrm{d}$ & 424 & 272 & (64) & & & 152 & (36) & & & \\
\hline Smoking $\geq 15 \mathrm{~g} / \mathrm{d}$ & 33 & 23 & (70) & & & 10 & (30) & & & \\
\hline Yearly income (SEK) & 783 & 513 & & 17064 & (10 705) & 279 & & 17190 & $\left(\begin{array}{lll}10 & 173\end{array}\right)$ & NS \\
\hline \multicolumn{11}{|l|}{ Blood pressure } \\
\hline Systolic & 811 & 524 & & 138.8 & (20.8) & 287 & & 137.0 & (20.3) & NS \\
\hline Diastolic & 811 & 524 & & 91.7 & (13.5) & 287 & & 90.7 & (12.1) & NS \\
\hline Cholesterol $(\mathrm{mg} / 100 \mathrm{ml})$ & 811 & 524 & & 247.4 & (42.1) & 287 & & 246.9 & (44.1) & NS \\
\hline Triglyceride $(\mathrm{mg} / 100 \mathrm{ml})$ & 811 & 524 & & 1.25 & $(0.69)$ & 287 & & 1.23 & $(0.73)$ & NS \\
\hline Body mass index & 808 & 522 & & 24.7 & (3.3) & 286 & & 24.8 & $(2.8)$ & NS \\
\hline Total & 811 & 524 & $(65)$ & & & 287 & (35) & & & \\
\hline
\end{tabular}

NS $=$ not significant.

cording to a classification especially developed for this period of time. ${ }^{112}$ It has five main groups: (I) high white collar workers; (II) low white collar workers, including master artisans and craftsmen, shop workers, and foremen; (III) farmers and tenant farmers; (IV) skilled blue collar workers, including craftsmen and

Table 2 Mean (SD) birth weights according to maternal sociodemographic characteristics, proteinuria, gestational age, and place of birth

\begin{tabular}{|c|c|c|c|c|}
\hline & \multirow[b]{2}{*}{ No } & \multirow[b]{2}{*}{$(\%)$} & \multicolumn{2}{|c|}{ Birth weight } \\
\hline & & & Mean & $(S D)$ \\
\hline $\begin{array}{l}\text { Maternal age }(y) \\
15-19 \\
20-24 \\
25-29 \\
30-34 \\
40-49 \\
\text { Missing }\end{array}$ & $\begin{array}{r}21 \\
104 \\
127 \\
106 \\
83 \\
32 \\
5\end{array}$ & $\begin{array}{l}(4) \\
(22) \\
(27) \\
(22) \\
(17) \\
(7) \\
(1)\end{array}$ & $\begin{array}{l}3540 \\
3582 \\
3699 \\
3851 \\
3693 \\
3913 \\
3742\end{array}$ & $\begin{array}{l}(803) \\
(652) \\
(534) \\
(598) \\
(613) \\
(501) \\
(799)\end{array}$ \\
\hline $\begin{array}{l}\text { Marital status } \\
\text { Married } \\
\text { Unmarried } \\
\text { Missing }\end{array}$ & $\begin{array}{r}401 \\
68 \\
9\end{array}$ & $\begin{array}{r}(84) \\
(14) \\
(2)\end{array}$ & $\begin{array}{l}3760 \\
3473 \\
3512\end{array}$ & $\begin{array}{l}(606) \\
(601) \\
(263)\end{array}$ \\
\hline $\begin{array}{l}\text { Parity at delivery } \\
\text { No children } \\
\geq 1 \text { child } \\
\text { Missing }\end{array}$ & $\begin{array}{r}123 \\
336 \\
19\end{array}$ & $\begin{array}{r}(26) \\
(70) \\
(4)\end{array}$ & $\begin{array}{l}3405 \\
3820 \\
3848\end{array}$ & $\begin{array}{l}(574) \\
(590) \\
(485)\end{array}$ \\
\hline $\begin{array}{l}\text { Social class } \\
\text { I } \\
\text { II } \\
\text { III } \\
\text { IV } \\
\text { V } \\
\text { Missing }\end{array}$ & $\begin{array}{r}14 \\
82 \\
32 \\
134 \\
209 \\
7\end{array}$ & $\begin{array}{r}(3) \\
(17) \\
(7) \\
(28) \\
(44) \\
(2)\end{array}$ & $\begin{array}{l}3631 \\
3683 \\
3809 \\
3712 \\
3708 \\
4026\end{array}$ & $\begin{array}{l}(778) \\
(570) \\
(579) \\
(635) \\
(595) \\
(816)\end{array}$ \\
\hline $\begin{array}{l}\text { Proteinuria } \\
\text { No } \\
\text { Yes } \\
\text { Missing }\end{array}$ & $\begin{array}{r}387 \\
61 \\
30\end{array}$ & $\begin{array}{r}(81) \\
(13) \\
(6)\end{array}$ & $\begin{array}{l}3732 \\
3542 \\
3841\end{array}$ & $\begin{array}{l}(617) \\
(569) \\
(534)\end{array}$ \\
\hline $\begin{array}{l}\text { Urbanisation level } \\
\text { Urban } \\
\text { Rural }\end{array}$ & $\begin{array}{l}295 \\
183\end{array}$ & $\begin{array}{l}(62) \\
(38)\end{array}$ & $\begin{array}{l}3710 \\
3720\end{array}$ & $\begin{array}{l}(616) \\
(599)\end{array}$ \\
\hline $\begin{array}{l}\text { Place of birth } \\
\text { Home deliveries } \\
\text { Hospital deliveries } \\
\text { Missing }\end{array}$ & $\begin{array}{r}372 \\
106 \\
0\end{array}$ & $\begin{array}{l}(78) \\
(22)\end{array}$ & $\begin{array}{l}3817 \\
3352\end{array}$ & $\begin{array}{l}(592) \\
(528)\end{array}$ \\
\hline $\begin{array}{l}\text { Gestational age (quar } \\
\geq 273(1) \\
274-288(2-3) \\
>288(4) \\
\text { Missing }\end{array}$ & $\begin{array}{r}110 \\
229 \\
94 \\
45\end{array}$ & $\begin{array}{r}(23) \\
(48) \\
(20) \\
(9)\end{array}$ & $\begin{array}{l}3448 \\
3776 \\
3877 \\
3710\end{array}$ & $\begin{array}{l}(636) \\
(555) \\
(515) \\
(780)\end{array}$ \\
\hline Total & 478 & $(100)$ & 3714 & (609) \\
\hline
\end{tabular}

artisans below the rank of masters; and (V) unskilled blue collar workers from urban or rural areas.

Obstetrical records were more often untraced in rural birth parishes than urban birth parishes (table 1). Moreover, among social class groups, farmers (social class III) had the highest rates of untraced obstetrical records. If the farmers' level was excluded there was no difference in the fathers' social status in 1913 between those whose records were found and those not found. In 1963, when the men in the cohort were 50 years old, there were no significant differences at all between the groups regarding social class, yearly income, and the traditional risk factors for cardiovascular diseases such as smoking habits, blood pressure, cholesterol, triglycerides, and body mass index.

\section{STATISTICAL ANALYSIS}

Summary statistics were computed using standard methods. The univariate analyses were conducted with $\mathcal{F M P}$ software release $3.02 .{ }^{13}$ Other data analyses were conducted with $S A S$ software release $6.07 .{ }^{14}$

For the correlation analyses, Spearman's non-parametric correlation coefficients were computed. Multivariate analyses were performed with the multiple logistic or linear regression technique. The isotonic regression technique was used to construct the regression surface of figure 2 . All tests were two tailed. Probability values less than 0.05 were regarded as statistically significant. Very small $\mathrm{p}$ values were denoted $<0.0001$.

\section{Results}

The mean maternal age at delivery (SD) was $29.5(6.3)$ years. Only $4 \%$ of the mothers were teenagers and $24 \%$ were 35 years old or older 
Table 3 Correlation matrix of variables possibly correlated to birth weight. $r=$ correlation coefficient and $p=$ the corresponding $p$ value

\begin{tabular}{|c|c|c|c|c|c|c|c|c|c|}
\hline & & Birth weight & Maternal age & Marital status & s Parity & Social class & Proteinuria & Gestational age & Urban level \\
\hline Maternal age & $\begin{array}{l}\mathbf{r} \\
\mathbf{p}\end{array}$ & $\begin{array}{l}0.137 \\
0.0028\end{array}$ & & & & & & & \\
\hline $\begin{array}{l}\text { Marital status } \\
(\text { married }=1 ; \text { unmarried }=2)\end{array}$ & $\begin{array}{l}\mathbf{r} \\
\mathbf{p}\end{array}$ & $\begin{aligned}-0.160 \\
0.0005\end{aligned}$ & $\begin{array}{r}-0.386 \\
0.0001\end{array}$ & & & & & & \\
\hline $\begin{array}{l}\text { Parity } \\
\text { (no children }=0 ; \geq 1=1 \text { ) }\end{array}$ & $\mathbf{r}$ & $\begin{array}{l}0.301 \\
0.0001\end{array}$ & $\begin{array}{l}0.454 \\
0.0001\end{array}$ & $\begin{array}{c}-0.263 \\
0.0001\end{array}$ & & & & & \\
\hline $\begin{array}{l}\text { Social class } \\
(\mathrm{I}-\mathrm{V})\end{array}$ & $\begin{array}{l}\mathbf{r} \\
\mathbf{p}\end{array}$ & $\begin{array}{l}0.009 \\
0.8523\end{array}$ & $\begin{array}{r}-0.100 \\
0.0255\end{array}$ & $\begin{array}{l}0.157 \\
0.0005\end{array}$ & $\begin{array}{l}0.020 \\
0.6694\end{array}$ & & & & \\
\hline Gestational age & $\begin{array}{l}\mathbf{r} \\
\mathbf{p}\end{array}$ & $\begin{array}{l}0.255 \\
0.0001\end{array}$ & $\begin{array}{l}0.068 \\
0.1518\end{array}$ & $\begin{array}{r}-0.133 \\
0.0048\end{array}$ & $\begin{array}{l}0.079 \\
0.1022\end{array}$ & $\begin{array}{r}-0.036 \\
0.4504\end{array}$ & $\begin{array}{l}0.007 \\
0.8856\end{array}$ & & \\
\hline $\begin{array}{l}\text { Urbanisation level } \\
(\text { urban }=1 ; \text { rural }=2)\end{array}$ & $\begin{array}{l}\mathbf{r} \\
\mathbf{p}\end{array}$ & $\begin{array}{l}0.040 \\
0.3819\end{array}$ & $\begin{array}{l}0.024 \\
0.5912\end{array}$ & $\begin{array}{r}-0.118 \\
0.0078\end{array}$ & $\begin{array}{l}0.007 \\
0.8756\end{array}$ & $\begin{aligned}-0.016 \\
0.7156\end{aligned}$ & $\begin{array}{l}0.032 \\
0.4841\end{array}$ & $\begin{array}{r}-0.047 \\
0.3160\end{array}$ & \\
\hline $\begin{array}{l}\text { Place of birth } \\
\text { (home }=1 ; \text { hospital }=2 \text { ) }\end{array}$ & $\begin{array}{l}\mathbf{r} \\
\mathbf{p}\end{array}$ & $\begin{array}{c}-0.324 \\
0.0001\end{array}$ & $\begin{array}{r}-0.253 \\
0.0001\end{array}$ & $\begin{array}{l}0.397 \\
0.0001\end{array}$ & $\begin{array}{r}-0.262 \\
0.0001\end{array}$ & $\begin{array}{l}0.116 \\
0.0090\end{array}$ & $\begin{array}{l}0.090 \\
0.0519\end{array}$ & $\begin{array}{r}-0.100 \\
0.0323\end{array}$ & $\begin{array}{c}-0.231 \\
0.0001\end{array}$ \\
\hline
\end{tabular}

(table 2). Eighty four per cent of the mothers were married and $14 \%$ were single. Twenty six per cent gave birth for the first time. Nearly three out of four were from social classes III or IV. Thirteen per cent had proteinuria or traces of proteinuria. Sixty two per cent were born in urban parishes and $38 \%$ in rural ones. Seventy eight per cent were delivered at home and $22 \%$ in a hospital. The mean (SD) gestational age at delivery was 280 (15) days. Mean birth weight was 3714 (609) g.

Mean birth weight increased with maternal age up to the age group 30 to 34 years. Compared with infants of unmarried mothers, infants whose mothers were married had higher birth weights. Mean birth weights were higher among offspring of parous women than of nulliparous women, increased with gestational age, and decreased with the presence of proteinuria. The mean birth weight of infants delivered at

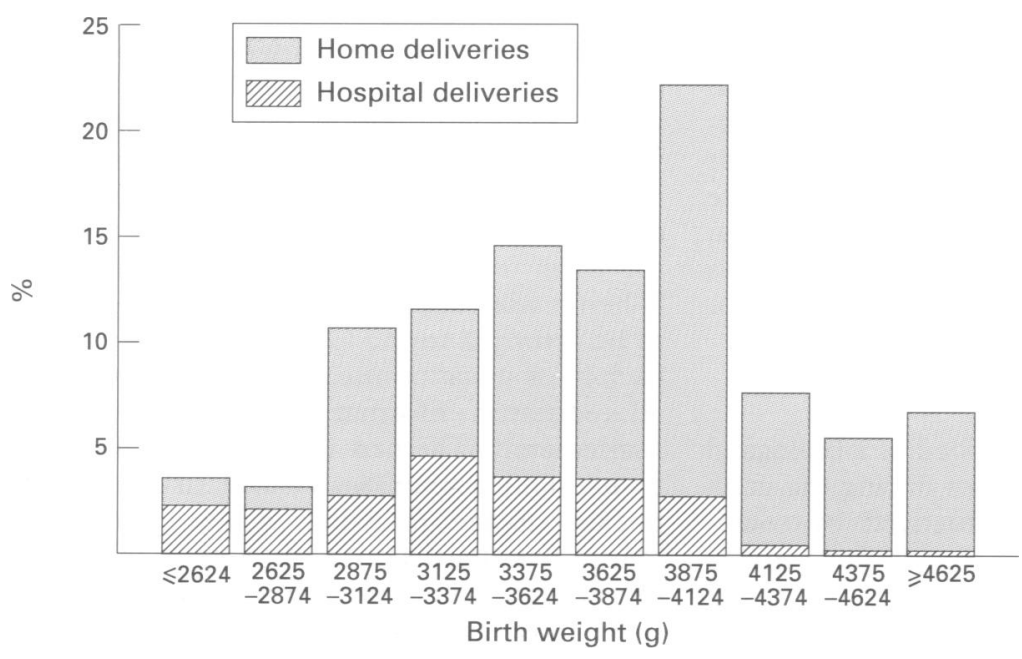

Figure 1 Distribution of birth weight (g) for hospital and home delivered babies in the study of men born in 1913, Sweden.

Table 4 Birth weights in hospital and home deliveries in relation to the exactness of notation

\begin{tabular}{|c|c|c|c|c|}
\hline & \multicolumn{2}{|c|}{ Hospital deliveries } & \multicolumn{2}{|c|}{ Home deliveries } \\
\hline & Birth weight & No & Birth weight & No \\
\hline $\begin{array}{l}\text { Birth weight in } \mathrm{g} \\
\text { Birth weight in } \mathrm{kg} \text { with one decimal } \\
\text { Birth weight in quarter } \mathrm{kg} \\
\text { Birth weight in } \mathrm{kg} \\
\text { Other birth weight notations } \\
\text { Missing information }\end{array}$ & 3352 & 106 & $\begin{array}{l}3761 \\
3785 \\
3866 \\
3870 \\
3888\end{array}$ & $\begin{array}{r}127 \\
68 \\
69 \\
92 \\
16 \\
29\end{array}$ \\
\hline
\end{tabular}

home exceeded the mean birth weight of infants delivered in hospital by $465 \mathrm{~g}$. There was no difference in the mean birth weights of babies born in urban and rural parishes. No obvious association between social class and mean birth weight was found.

In table 3 a correlation matrix of variables possibly correlated to birth weight is shown. Maternal age, marital status, parity, proteinuria, gestational age, and place of birth were all significantly correlated to birth weight, whereas social class and the urbanisation level were not. Maternal sociodemographic characteristics such as age, marital status, parity, and social class were all significantly correlated to place of birth, and so was the urban/rural level. Compared with mothers delivered at home, mothers delivered in a hospital tended to be younger and were more often from lower social classes, unmarried and nulliparous.

The birth weight distribution of home and hospital deliveries is illustrated in figure 1 . Compared with hospital deliveries, the birth weight distribution of home deliveries was shifted to the right. Most of the children with low birth weights were born in a hospital and nearly all of the children with heavy weights were born at home.

To see if the weight difference could be due to measurement bias, an analysis of the accuracy of birth weight notations was done. The various levels of notational exactness are indicated in table 4. In all hospital deliveries, birth weights were noted in grams, while in home deliveries several levels of exactness were used. When home delivery birth weights noted in grams were used, the difference in birth weight between infants born at home and in hospital remained (409 $\mathrm{g}$ ). In addition, home delivery birth weights with a more imprecise notation were consistently higher than birth weights in hospital deliveries.

To see if the variables that were related to birth weight in univariate analyses were independently correlated to birth weight, a multiple regression analysis was performed (table 5). Place of birth, gestational age, parity, and proteinuria remained significantly and independently correlated to birth weight, whereas maternal age and marital status were not.

The combined impact of the variables place of birth, parity, and gestational age on birth 
Table 5 Stepwise multiple regression analyses with birth weight $(g)$ as the dependent variable.

\begin{tabular}{lrrll}
\hline & $\begin{array}{l}\text { Regression } \\
\text { coefficient }\end{array}$ & $\begin{array}{l}\text { Partial } \\
(\%)\end{array}$ & $\begin{array}{l}\text { In the } \\
\text { model (\%) }\end{array}$ & p value \\
\hline Place of birth & -332.79 & 10.58 & 10.58 & $<0.0001$ \\
Gestational age & 10.06 & 6.70 & 17.27 & $<0.0001$ \\
Parity & 263.41 & 3.71 & 20.98 & $<0.0001$ \\
Proteinuria & -164.35 & 0.86 & 21.85 & $<0.05$ \\
$\begin{array}{l}\text { Maternal age } \\
\text { Marital status }\end{array}$ & & & & NS \\
Total model & & & 21.97 & NS \\
NS =not significant & & &
\end{tabular}

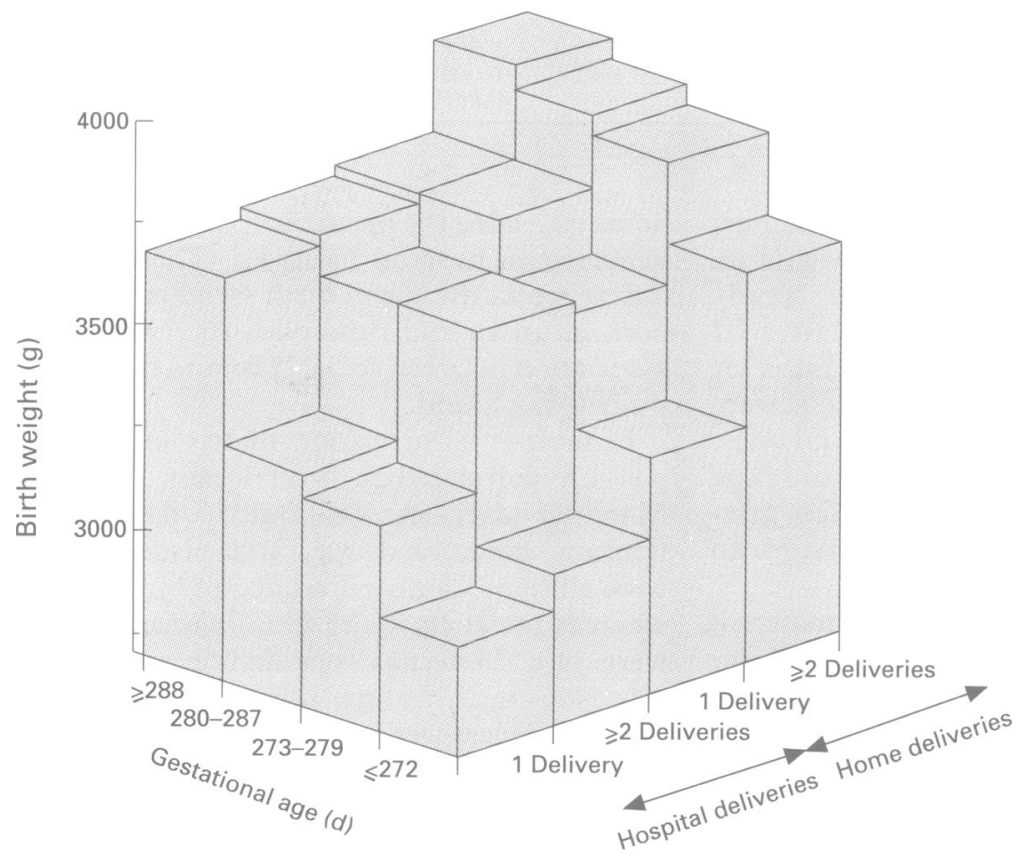

Figure 2 Birth weight in relation to place of birth, parity, and gestational age in the study of men born in 1913, Sweden. biased, since urbanisation level and social class were not significantly correlated to birth weight (table 3).

Obstetrical records from 1913 proved to be of good validity. Factors well known to influence birth weight in modern studies also influenced birth weight in the present investigation. For example, the increase in birth weight with gestational age is very similar to that reported in studies using more recent data. ${ }^{1819}$ The birth weight decrease related to proteinuria has also been confirmed in other studies. ${ }^{2021}$ The mean birth weight difference between infants with parous and nulliparous mothers was of a larger magnitude than obtained in investigations using data from more recent deliveries. ${ }^{223}$ However, although of less magnitude, the parity related increase in birth weight continues after the second birth. ${ }^{24}$ Compared with the present, mean parity was generally higher in Sweden 80 years ago, which may be one explanation for the relatively high birth weight difference obtained in infants with parous and nulliparous mothers.

The high mean birth weight $(3714 \mathrm{~g})$ was obtained from a cohort of survivors of men at 50 years and cannot be compared with the mean birth weight of newborns. Boys have higher birth weight than girls and the mean birth weight was probably also influenced by the loss of those who died before 50 years of age.

The birth weight difference between children born inside and outside hospital was surprisingly large, although it was reduced when the influence of other factors was taken into account. In spite of the fact that birth weight measurements were more imprecise among home deliveries, the data in table 4 indicate that the birthweight difference is unlikely to be due to measurement diversities.

Recall bias or other notational errors may also have influenced the differences in birth weight between hospital and home deliveries. The midwives' record books, used in home deliveries, were altered from 1912 and were the same all over Sweden. The midwife received the book from the general practitioner (GP). When it was full, or the midwife moved, it was to be returned to the GP. On the first pages of each book it was pointed out that she must note all requested information from all deliveries immediately. The new book was therefore easy to use and conveniently sized to fit into the pocket of the midwife's apron. These circumstances have most certainly contributed to the validity of the obstetrical data.

Another possible explanation for the birth weight differences might be a difference in midwifery competence between those working in a hospital and those working in the community. However, all midwives were required to have formal education. In Sweden, the dramatic decline in maternal mortality in the late 19 th century has primarily been attributed to the modern training of midwives and the introduction of antisepsis. ${ }^{25}$ A Swedish law in 1913 stipulated that there was to be at least one midwife in each parish, which was the smallest administrative unit. One of the two schools in Sweden for training midwives was 
located in Gothenburg. All hospital births in this area took place in the hospital to which the school was affiliated. Thus, the improved quality of midwifery education also influenced the quality of home deliveries. The midwives were supervised by the local GP. The supervision was documented in specially kept conduct books, which are still available. From the notes in these books, it is possible to evaluate the skills and performance of individual midwives at the time. The GPs seemed to be generally satisfied with the midwives.

A fourth possible explanation for the differences in birth weight between hospital and home deliveries could be selective retrieval of birth records. The hospital records were filed in a uniform manner and were therefore relatively easy to find. Records from home deliveries, on the other hand, are stored in many different types of archives and some records have been lost, especially in the countryside. This has led to better retrieval of birth data from urban parishes $(p<0.0001)$. But when the midwives record books from home deliveries had been well archived, the drop outs were few. Most of the records not found were from areas where the whole archives were lost. As the mean birth weight for both urban and rural parishes was equal, selective retrieval of birth records is unlikely to have influenced the differences in birth weight between hospital and home deliveries.

The hospital-home birth weight difference is also found in English studies. In studies from Hertfordshire, England, including mostly home deliveries from 1911-30, the mean birth weights were around $3600 \mathrm{~g}$ for those who were alive at 20 years of age, compared with $3817 \mathrm{~g}$ in our study. ${ }^{21526}$ In Sheffield, England, in a study that included only hospital deliveries from 1907-24, the mean birth weight for survivors was $3311 \mathrm{~g}$ (compared with $3352 \mathrm{~g}$ in our study). ${ }^{27}$ Thus, in these English studies the birth weight difference between home and hospital deliveries was $290 \mathrm{~g}$, which is less than the birth weight difference obtained in the present study ( $465 \mathrm{~g}$ ).

The cause of the hospital-home birth weight difference, which remained after controlling for possible confounding factors, is unclear. It may reflect differences in socioeconomic or demographic factors other than those controlled for in the present study. In the English studies, as well as in the present one, the better off women were more often delivered at home. ${ }^{17}$ According to the Public Health Committee of Gothenburg in 1916, women could be delivered inside a hospital free of charge while those delivered at home often, if possible, payed some part of the midwifery commitment - this involved checking up the mothers and the newborns sometimes during the following three weeks.

An ideal study design for investigating the importance of birth weight for future health would be a population based cohort study in which the cohort is followed from birth to death with repeated examinations. ${ }^{528}$ No such study exists, but one is in the course of preparation. This is even more necessary since it has been suggested that a redeeming factor, perhaps a conventional risk factor, adds to the effect caused by low birthweight instability. ${ }^{1329}$

In conclusion, there are reasons to believe that the obstetrical data from 1913 are reasonably valid, that there are no obvious selection biases, and that the hospital-home birthweight difference seems to be real.

This study was supported by grants from the Swedish Medical Research Council (B95-27X-11269-01A), Göteborg University, and Uppsala University.

1 Barker DJP. Mothers, babies, and diseases in later life. London: BMJ Publishing Group, 1994.

2 Osmond C, Barker DJP, Winter PD, Fall CHD, Simmonds SI. Early growth and death from cardiovascular disease in women. $B M \mathcal{F}$ 1993;307:1519-24.

3 Fall CHD, Osmond C, Barker DJP, et al. Fetal and infant growth and cardiovascular risk factors in women. $B M \mathcal{Y}$ 1995;310:428-32.

4 Barker DJP. Fetal origins of coronary heart disease. $B M \mathcal{F}$ 1995;311:171-4.

5 Matthes JWA Lewis PA, Davies DP, Bethel JA. Relation Matthes JWA, Lewis PA, Davies DP, Bethel JA. Relation in adolescence. BMF 1994;308:1074-7.

6 Paneth N, Susser M. Early origin of coronary heart disease (the "Barker hypothesis"). BMf 1995;310:411-2.

7 Elford J, Shaper AG, Whincup P. Early life experience and cardiovascular disease - ecological studies. F Epidemiol Community Health 1992;46:1-8.

8 Ben-Shlomo Y, Davey Smith G. Deprivation in infancy or in adult life: which is more important for mortality risk? Lancet 1991;337:530-4.

9 Welin L, Svärdsudd K, Ander-Peciva S, et al. Prospective study of social influences on mortality: The study of men born in 1913 and 1923. Lancet 1985;i:915-8.

10 Historisk statistik för Sverige. Del 1. Befolkning. Andra Uppl. 1720-1967. Statistiska Centralbyrån. (Historical Statistics of Sweden. Part 1. Population. 2nd ed. 1720 1967. National Central Bureau of Statistics). Stockholm, 1967. National

11 Eriksson M, Åkerman S. Geografisk och social rörlighet (Geographic and social mobility). Scandia 1974;40:260 310 .

12 Thernstrom S. The other Bostonians. Poverty and progress in the American metropolis 1880-1970. Cambridge, MA: CUP 1973.

13 FMP software for statistical visualization. Cary, NC: SAS Institute, 1994.

14 SAS Software Release 6.07. Cary, NC, USA: SAS Institute, 1989.

15 Fall CHD, Vijayakumar M, Barker DJP, Osmond C, Duggleby $\mathrm{S}$. Weight in infancy and prevalence of coronary heart disease in adult life. $B M \mathcal{F}$ 1995;310:17-9.

16 Lucas A, Moreley $R$. Does early nutrition in infants born before term programme later blood pressure? $B M \mathcal{F} 1994$; 309:304-8.

17 Barker DJP, Bull AR, Osmonds C, Simmonds SJ. Fetal and placental size and risk of hypertension in adult life. $B M \mathcal{Y}$ 1990;301:259-62.

18 Cnattingius S, Axelsson O, Eklund G, Lindmark G. Early pregnancy screening for intrauterine growth retardation. Early Hum Dev 1984;10:35-44.

19 Wikström I. Large infants: antenatal diagnosis and risk a delivery. Uppsala: University of Uppsala, 1992, MD Thesis.

20 Cnattingius S, Axelsson O, Eklund G, Lindmark G, Meirik $O$. Factors influencing birthweight for gestational age with special respect to risk factors for intrauterine growth retardation. Early Hum Dev 1984;10:45-55.

21 Cnattingius S, Axelsson O, Eklund G, Lindmark G. Screening for intrauterine growth retardation in late pregnancy. ing for intrauterine growth retard

22 Nordström ML, Cnattingius S. Smoking habits and birthweights in two successive births in Sweden. Early Hum weights in two succes $1994 ; 37: 195-204$

23 Brooke OG, Anderson HR, Bland JM, Peacock JL, Stewart CM. Effects on birth weight of smoking, alcohol, caffeine, socioeconomic factors, and psychosocial stress. $B M \mathcal{F}$ 1989;298:795-801

24 Karn MN, Penrose LS. Birth weight and gestational time in relation to maternal age, parity and infant survival. $A n n$ Eugenics 1952;16:147-68.

25 Högberg U. Maternal mortality in Sweden. Umeå: University of Umeå, 1985, MD Thesis.

26 Barker DJP, Winter PD, Osmond C, Margetts B, Simmonds SI. Weight in infancy and death from ischemic heart disease. Lancet 1989;ii:577-80.

27 Barker DJP, Osmond C, Simmonds SJ, Wield GA. The relation of small head circumference and thinness at birth to death from cardiovascular disease in adult life. $B M F$ 1993;306:422-6.

28 Robinson RJ. Introduction. In: Barker DJP, ed. Fetal and infant origins of adult disease. London: BMJ Publishing Group, 1992:1-20.

29 Barker DJP, Gluckman PD, Godfrey KM, Harding JE, Owens JA, Robinson JS. Fetal nutrition and cardiovascula disease in adult life. Lancet 1993;341:938-41. 